\title{
Perceptions and attitudes of the local people towards bats in the surroundings of the big colony of Tadarida brasiliensis, in the Escaba dam (Tucumán, Argentina)
}

Maria Cecilia Castilla ${ }^{1,2,3^{*}}$, Claudia Campos ${ }^{4}$, Sonia Colantonio ${ }^{5}$, Monica Díaz ${ }^{2,3}$

\begin{abstract}
When biodiversity conservation of non-charismatic species is a priority, local people perception and value attributed to species are of vital importance. The big colony of bats (Tadarida brasiliensis) in the Escaba dam located at the Yungas forest is an emblematic case for the conservation of bats in Argentina. The objective of this study was to evaluate the perception and attitude about the bats of the people living around the Escaba dam in order to redirect conservation efforts and education plans. Semi-structured surveys and participant observation were used to survey the information; and generalized linear models to analyze the data. The local inhabitants do not recognize the diversity of bat species and mention only blood-sucking and insectivorous bats. The results show a positive trend in perception and attitude, influenced by the recognition of the role of bats as insect controllers and a feeling of identity generated by the colony. The perception becomes more positive as age advances and in those who reached the secondary level of education. New ways of measuring perception and attitude are presented, such as describing the forms of bat exclusion. All this must be considered in the development of the management plan, which should consider the possible local use of guano as a fertilizer, sustainable tourism and educational actions aiming at differentiating the species (i.e. this is not a hematophagous bat colony), the role of the colony at controlling possible diseases and the ecosystem services associated with these species.
\end{abstract}

Keywords: Ethnoconservation, Ethnozoology; Bat Colony; Perception

\footnotetext{
${ }^{1}$ Centro de Investigaciones y Transferencia de Catamarca (CITCA). CONICET-UNCA. Prado 366 SFVC. CP4700

${ }^{2}$ CONICET, Programa de Investigaciones de Biodiversidad Argentina (PIDBA), Facultad de Ciencias Naturales e IML, UNT y Fundación Miguel Lillo

${ }^{3}$ Programa de Conservación de los Murciélagos de Argentina (PCMA)4 Instituto Argentino de Investigaciones de las Zonas Áridas (UNCuyo- Gobierno de Mendoza-CONICET), Mendoza, Argentina

${ }^{5}$ Universidad Nacional de Córdoba
}

*Corresponding author. $₫ \mathrm{E}$-mail address: mceciliacastilla@gmail.com 


\section{INTRODUCTION}

According to the knowledge system of a community, people give value to species by their beauty, usefulness, or rarity, and the visual attractiveness strongly influences the opinion of people on whether a species should be protected or not (Heywood, 1995; Leader Williams and Dublin, 2000; Gunnthorsdottir, 2001; Prokop and Fančovičová, 2013). Human preference toward large charismatic species has directed conservation efforts mainly to them (Simberloff, 1998; Dubois, 2003; Sitas et al., 2009), thus birds, mammals, and fishes are privileged species because they are more socially accepted than reptiles, amphibians, and invertebrates (Czech and Krausman, 2001; Clucas et al., 2008); however, there are exceptions. For example, bats are mammals, but they are considered cryptic species (Clucas et al., 2008) and are associated in popular media with blood sucking evil vampires (Knight, 2008; Prokop et al., 2009).

The current challenge worldwide is to maintain or improve ecosystem services, broadly defined as the benefits that people obtain from ecosystems (MEA 2005). Although these services refer to biological diversity (diversity of organisms, ecosystems and their associated ecological and evolutionary processes), this concept is only revealed in the presence of the social component and recognizing the central role played by culture in the links between people and nature (Reyers et al., 2013, MartínLópez et al., 2014). For example, bats participate in many ecological processes (pollination, seed dispersal, control of insect populations) (Kunz et al., 2011), offering positive contribution of nature to people. Some communities in Bolivia use blood of bats for the preparation of curative ointments
(Lizarro et al., 2010). In different countries of America, guano is used as fertilizer (Frank, 1998). Bat observation has not been practiced as often as bird watching; however, it is a recreational activity that has brought economic benefits to the people who live near the refuges of big colonies (Tapper, 2006; Bagstad and Wiederholt, 2013).

The beliefs, myths and histories existing in the symbolic sphere of bats, which are transmitted from generation to generation, also have a great influence on the valuation of the people (Prokop et al., 2009; Navarro Noriega, 2015; Musila et al., 2018). The indigenous of Mexico had an attitude of conservation towards them because they were idolized, and at the same time, feared. The arrival of European culture and the introduction of cattle led to the growth of vampire populations due to the large food availability; thus, the negative interactions between vampires and people increase. Since then, a predominantly negative assessment was established, fueled by stories like Dracula, which spread to bats in general (Kunz, 1984; Retana Guiascón and Navarijo Ornelas, 2012).

When people assign a high value to a species, the sense of identity and belonging to their culture and worldview is strengthened (Lameda Camacaro, 2011). The cultural value assigned to species could be determined through the study of the perceptions and attitudes of the local people towards them (Purdy and Decker, 1989). On one hand, the perception depends on physical stimuli and on the organization of sensations through symbolic thought and cultural and historical structures, and therefore can vary in time and space (Vargas Melgarejo, 1994). The attitude, on the other hand, is a predisposition to act and it can be considered permanently, as well as the perception, as positive or negative by means 
of three dimensions: cognitive, evaluative and behavioral (Cacioppo et al., 1981; Eagly and Chaiken, 1993). Kellert (1997) proposes a classification of people attitudes based on the value of nature: naturalist, scientistecologist, aesthetic, symbolic, humanist, moralist, negativist, dominating and utilitarian. It is assumed that the values, characteristics of the object of conservation, the experiences lived, and the previous knowledge accumulated by the community will influence the attitude of people. In this way, attitudes and perceptions towards animals in general and bats differ among human groups according to demographic and socioeconomic variables (Kellert, 1997; Prokop et al., 2009).

Regarding the socio-demographic variables, when age and educational level increases, the perception becomes more positive and the knowledge about the bats becomes greater (Shafie et al., 2017; Musila et al., 2018). In relation to gender, the studies are not conclusive, because many results showed no differences between men and women (Ohemeng et al., 2017; Shafie et al., 2017; De Prada and BarragánTabares 2018; Musila et al., 2018). However, considering that that frogs are unpopular like bats, it was found that women show greater tolerance to frogs than men (Prokop et al., 2016). While some studies suggest that the occupation or work task does not significantly affect the perceptions and attitudes towards the species (Shafie et al., 2017), other authors argue that people can evaluate and value wildlife according to their daily routine and where they live and work (Miller and Hobbs, 2002).

At large scale, bats are threatened by habitat loss, emerging diseases, pollution, destruction of shelters and persecution (Díaz et al. 2013; Aguirre et al., 2016). Programs directed to bat conservation worldwide and particularly in Latin America recognize that it is necessary to understand the diversity of local knowledge systems and the variety of views in order to improve conservation and education strategies (Aguirre et al., 2014; Isma'll 2015; Kingston, 2016). In Argentina, the big colony (2 million individuals) of insectivorous bats (Tadarida brasiliensis) in the Escaba dam (Tucumán province) (Gamboa Alurralde, in prep.) is emblematic for the conservation of bats within the framework of the Programa de Conservación de los Murciélagos de Argentina (PCMA). The colony has attracted the attention of different stakeholders, such as scientific researchers, government officials, local people and tourists. The main aim of this study was to analyze how perception and attitude regarding the bats of local people living around the Escaba dam, are affected by socioeconomic variables, knowledge, and degree of contact with bats. The work also explores local uses and myths/beliefs related with bats.

\section{MATERIAL AND METHODS}

\section{Study area}

The Escaba region ( $27^{\circ} 66^{\prime} \mathrm{S}-65^{\circ} 76^{\prime} \mathrm{W}$; Tucumán province, Argentina) is located 25 $\mathrm{km}$ from the Alberdi city and $100 \mathrm{~km}$ southwestern Tucumán city. The region covers a surface of $575 \mathrm{~km} 2$ and includes the towns of Escaba de Arriba, Villa de Escaba, Escaba de Abajo and Batiruana (Figure 1).

The climate is warm and humid-subhumid to temperate with dry, not harsh winters, and hot, humid and rainy summers, allowing forest formation (Santillán de Andrés and Ricci, 1980). The annual precipitations are from 900 to $1300 \mathrm{~mm}$, being February the 

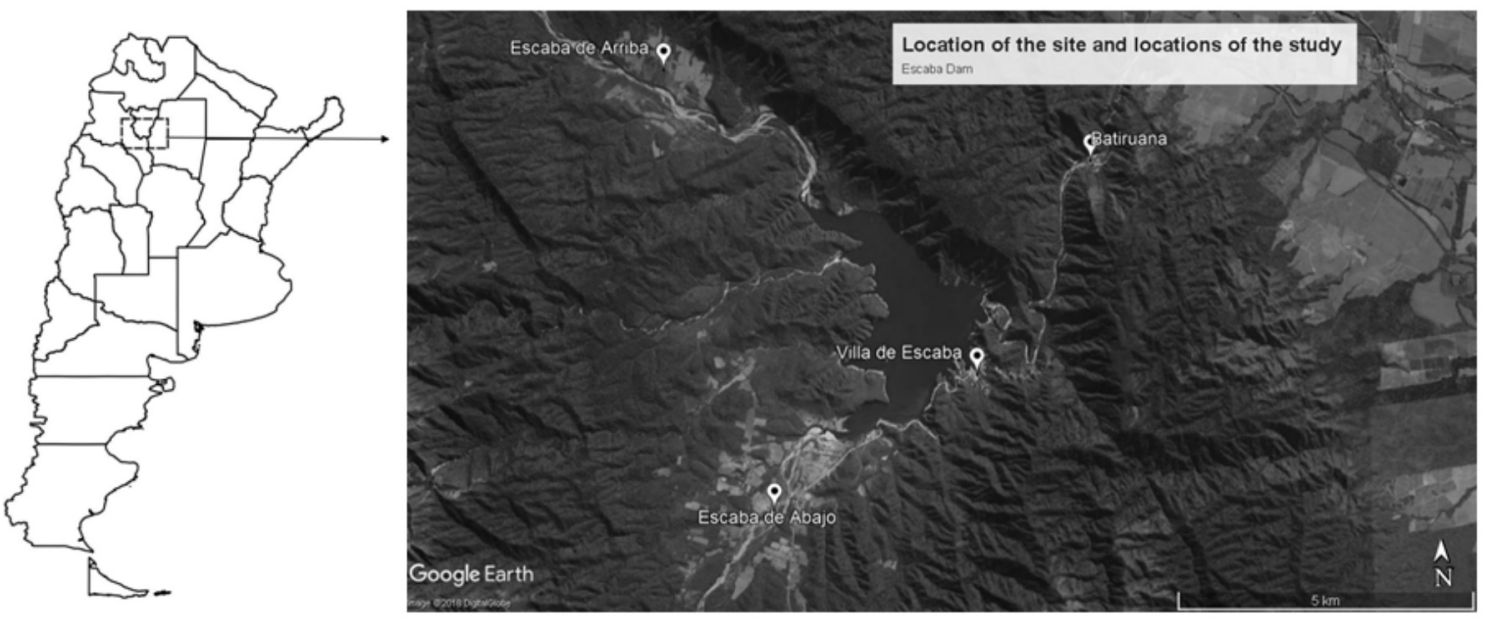

Figure 1. Location of the site and locations of the study.

wettest (167 $\mathrm{mm}$ average) and August the driest (30 $\mathrm{mm}$ average) months. The average annual temperature is $18^{\circ} \mathrm{C}$. The vegetation of the area is included in the ecoregion of Yungas in the southernmost limit of this plant formation, where ecotone is generated with the ecoregion Chaco (Bukart et al., 1999). At the junction between the Singuil and Chavarría rivers, the Escaba dam was built between 1946 and 1948 . Annually the dam has cyclical fluctuations of the water level; which corresponds to a marked winter season with less rainfall (Kühn and Rohemeder, 1943; Mon and Urdaneta, 1972).

Since 1992, a large colony of the migratory species Tadarida brasiliensis located in the Escaba dam has been studied. Since 2000, this colony was declared as "natural monument" and protected by Provincial Law $N^{\circ} 7.058$. From 2006 to 2008, some management measures were carried out in order to relocate the colony and reduce its size (Regidor et al., 2003; Mosa, 2014), in more than 50\% according to recent studies (Gamboa Alurralde et al., 2014). This background allowed the Escaba dam to be internationally designated as an important site for bat conservation (Miotti, 2014).

\section{Data collection}

During 2012-2016 semi-structured surveys and participant observation were conducted (Bernard, 1995; Costa Neto et al., 2009) to local people living in Batiruana, Escaba de Arriba, Villa de Escaba and Escaba de Abajo. Each survey consisted in two sections, one referring to personal and socio-economic information (name, job, age, gender, education and locality) and second section with questions related to the bats. The methodological approach was in accordance with the Code of Ethics of the International Society of Ethnobiology (2006). The free, prior and informed consent of the participants was obtained before interviewing them.

The work of people was grouped into categories according to the possibility of contact with nature in general and with bats in particular: farmers and ranchers, employees of companies, people dedicated to tourism and services, housewives. The occupation of retired persons was classified 
according to the activity performed at the time of receiving the benefit. The educational levels were grouped into four categories: no formal education, primary education, secondary education and high education (Table 1).

Bat species were grouped into ethnospecies, considering the folk identity recognized by local people, referred by a vernacular name (Madeiro et al., 2016). People were asked about: a) number of ethnospecies of bats that recognize, where species live, what group of animals they associate with, feeding, and transmission of diseases (knowledge); b) direct or indirect use or utility of bats; c) myths or beliefs about bats; d) personal contact with bats; e) conservation value; f) adjectives that describe bats (perception); f) actions carried out in the presence of bats in the house (attitude). In addition, people were asked about their support for bat conservation. According to Kellert (1997) this answer was used to classify the typologies of the attitude.

Data was analyzed by descriptive statistics taking into account an ethnozoological approach (Albuquerque et al., 2016; Alves and Albuquerque, 2017). For the analysis of perception and attitude generalized linear models (GLM) were fitted with a binomial distribution because the response variables perception and attitude can be positive or negative. Analysis were carried out using R software (RStudio Team, 2015). The explanatory variables considered were: 1) socioeconomic variables: age, gender, occupation, educational level, location; 2) knowledge: obtained by the total sum of points assigning 20 points to each corresponding answer, and 3 ) degree of contact with bats (4 levels): 0 when a person never saw or touched a bat, 1 if he/she saw a bat, 2 if he/she lived and 3 if he/she also touched the bat.

\section{RESULTS}

\section{Local knowledge about bats}

A total of 43 surveys were carried out for the four locations: Batiruana (8), Escaba de Arriba (7), Escaba de Abajo (22) and Villa de Escaba (6); 23 men and 20 women which makes up a $13 \%$ of the population over 16 years old and covers $39 \%$ of the families of the area. The average age of the women surveyed was 47 (range 26-79), and the average of men 53 (range 24-72).

Regarding the ethnic origin, in all families there are ascending groups from the provinces of Tucumán and Catamarca or Europeans. The mixture with the European population was accentuated since the Second World War, as many technicians, engineers and workers came to the area for the construction of the dike. All the interviewees, except an Evangelical family, professed the Catholic religion.

Of the total number of people of working age, $64 \%$ did not have formal employment. Of the people interviewed $30 \%$ are farmers (category 1), 16\% work in the hydroelectric company (category 2), $26 \%$ live of tourism and various services (warehouses, horse rental, etc.) (category 3 ) and $28 \%$ were housewives (category 4). Regarding the levels of education achieved $14 \%$ of the people interviewed did not have formal education (category 1), 53\% have primary education (category 2), 26\% secondary education (category 3) and $7 \%$ high education (category 4).

Regarding the degree of knowledge, people recognized between one (6\%), two $(79 \%)$ and three $(15 \%)$ ethnospecies of the 15 species present in the area (see Gamboa Alurralde et al., 2016, 2017). The most 
frequent classification element was feeding, followed by anatomical aspects such as the presence of free tail and, to a lesser extent, size and coloration (textual expression local people 31: "in the area there are only two, the one with a pointed ear and the one with round ear ", local people 29: "the one of the dam and the vampire", local people 24: "I have seen one small and the big one", local people 27: "there is one black and another reddish"). The "vampire" is also called "guampiro" or "camacho" and is recognized as the largest species. In addition to the bat "mouse tail" they also mentioned the "criollo bat", which was not possible to assign to a known species despite having the description of the people. Of the 43 respondents, 42 (98\%) mentioned that the bats feed on insects, $30(70 \%)$ of blood, 4 $(10 \%)$ of fruits and only two people $(5 \%)$ mentioned the existence of bats that feed on nectar.

Regarding the taxonomic position of the bats, 21 people $(49 \%)$ place them among rodent, without recognizing that both groups are mammals; 10 people (23\%) consider mammals, five (12\%) birds, two $(5 \%)$ butterflies and five people $(12 \%)$ did not respond. Of the total interviewees $25(58 \%)$ expressed that any disease is transmitted by bats and $18(42 \%)$ ensured that they transmitted diseases. Of those, $10(23 \%)$ mentioned the rabies or its symptoms, while seven $(16 \%)$ referred to the bite or poisoning of the vampire without identifying the virus; and only one person (2\%) mentioned the transmission of a disease in the feces. The people $(100 \%)$ identified that the bats live in human constructions, nine $(21 \%)$ mentioned caves, seven $(16 \%)$ trees and five $(12 \%)$ mentioned that they can live in mountains and tobacco fields.

Regarding the uses that people in the area make of bats, of the total number of respondents only 17 (38\%) mentioned an indirect use, which is guano as a fertilizer. At least two ways of preparation could be identified: in infusion and in powder, which is used both in garden plants and in orchards only at a family scale and not in larger-scale crops. The operators of the company declared that the guano is extracted every year from the cavity of the dam and discharged towards the water outlet and that the company does not allow them to sell it (textual inhabitant 23: "the company does not do anything with the guano, and we want to take it out to sell it").

In terms of myths and beliefs, five (12\%) people mentioned that bats are blind, two (5\%) people answered that they all suck blood, and $17(39 \%)$ that they are old rats that turned into bats (textual inhabitant 42: "I saw him inside the corn husk one day, he was already short, his wings were coming out". This last mention, in addition to be the most widespread, means that in bats has several "mythical" connotations.

Regarding previous experiences with bats, only one person said that he had never seen a bat, 21 interviewees (49\%) have lived with bats daily in their homes or at work, and $18(42 \%)$ have touched them. In order to have a parameter to assess the risk, we inquired about the care they had taken at the time of touching them, of the 18 people, 11 $(25 \%)$ had not taken any care while the rest had used gloves, sticks or tweezers.

\section{Perceptions, attitudes and actions towards bats.}

The people mentioned 30 animals that should be conserved among which the bats occupied the sixth place after the corzuela (Mazama sp.), mountain pig (Tayassu pecari), parrots (Amazona sp.), mountain turkey (Penelope obscura) and pumas 


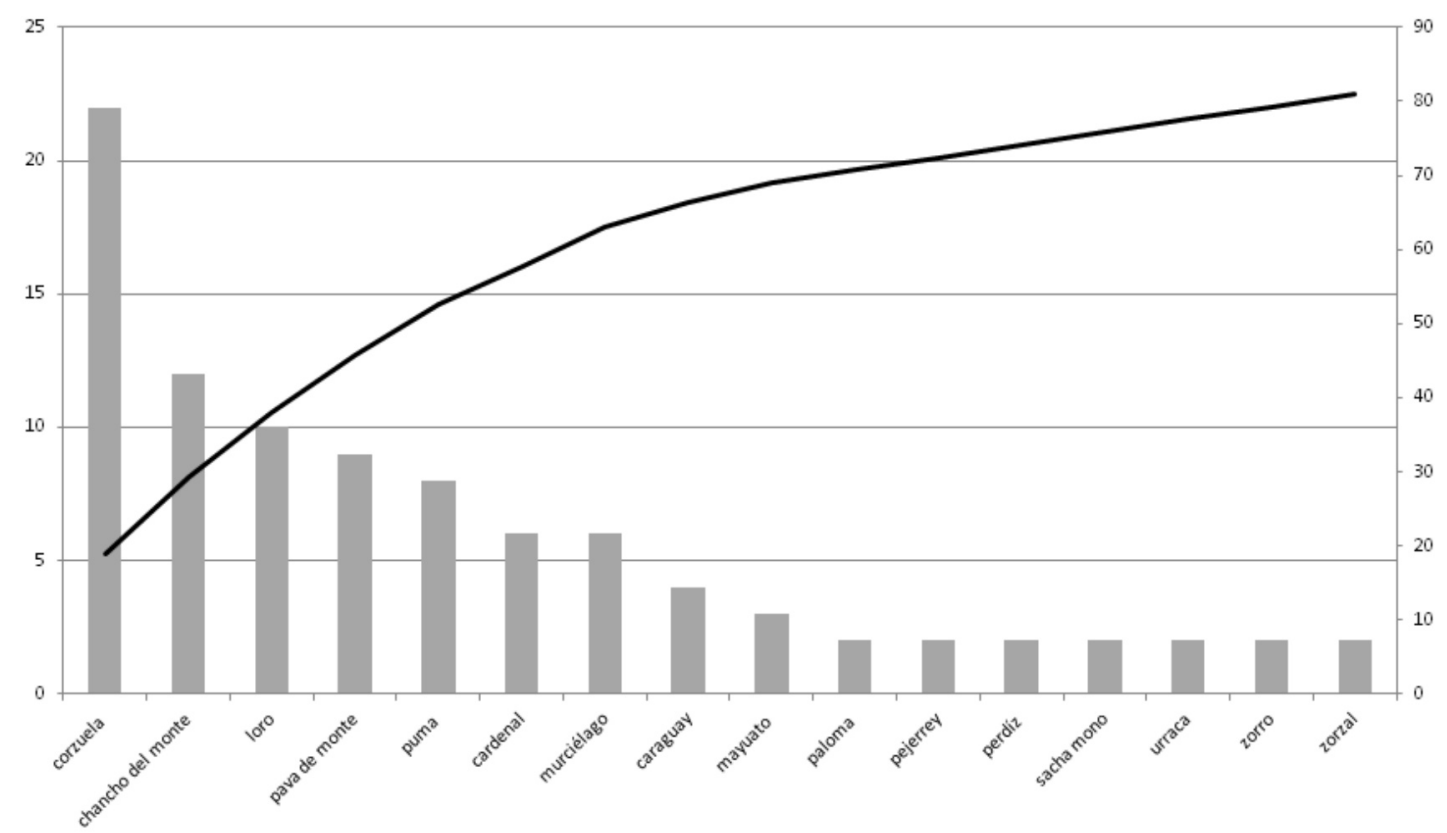

Figure 2. Animal species that must be conserved according to the people of the Escaba area. The bars indicate the absolute frequency of mentions and the curve the cumulative relative frequency.

(Puma concolor) (Figure 2); and these six animals account for $60 \%$ of the total mentions. All the aforementioned animals are native, and people also mentioned the introduced silverside (truchas), present in the Escaba Dam, among the species that have been conserved.

The interpretation of the adjectives used to qualify bats allowed us to establish that 19 people $(44 \%)$ showed a positive perception (i.e. neutral ratings such as "do not disturb" or "do not hurt", mentions that refer to ecosystem services they provide, mentions that are clearly positive as "I like it, they are cute"), while $24(56 \%)$ reflected a negative perception (i.e. they refer to their appearance or aesthetic value, fear and the damage they cause). According to the results of the models (Table 1), the secondary level of education and the people's age are the variables that better explain the perception that people have about bats.

When people were asking about the methods of exclusion, that is to say how they extract the bats out off human constructions, six people (14\%) mentioned that they never applied or observed how an exclusion is made, while the rest of the (37) people mentioned two types of handlings: harmless $(51 \%)$ and lethal (35\%). Fifty one percent of the interviewees chose non-lethal or harmless ways towards the bats to get them out of the home. The ways to scare away the bats were with rags, brooms, turning on the light and, if they are installed in the house, they usually place unidirectional exits to empty the place and then seal the entrances. Four people mentioned that they do not directly take them out and in general they talked about taking preventive measures so that they do not "aquerencien" at home. The lethal methods chosen by $14 \%$ imply the use of toxins like the Gamexane, sticks and leaving them locked in the refuge sites.

For the response variable "attitude of the residents to the presence of bats in their 
homes", the model did not show a significant the colony as a tourist offer $(28 \%)$. effect of any explanatory variable, except for Percentages lower than $10 \%$ of the answers a slight tendency to use non-lethal methods correspond to moralistic assessments ("they of exclusion by women ( $Z=1,667 ; p=$ are part of nature") and dominance 0.095).

Regarding the assessment of attitudes, according to the proposal of Kellert (1997), the most widespread was the ecological one ("controlling the damage they cause"). In addition, a valuation was detected related to the local identity and sense of belonging of the dike bat colony.

that refers to the ecological function of The only assessment that could be control of insect populations $(60 \%$ of explained by socio-demographic factors was responses), followed by a utilitarian use of the moralistic value of bats (Table 2).

Table 1. Results of the GLM for the response variable "perception of the bats by the people".

\begin{tabular}{|c|c|c|c|c|c|c|}
\hline \multicolumn{3}{|l|}{ Coefficient } & Estimate & Stand error & Z Value & $\operatorname{Pr}(>|z|)$ \\
\hline \multicolumn{3}{|l|}{ Intercept } & 11,39 & 10750 & 0,001 & 1,00 \\
\hline \multirow{4}{*}{ Occupation } & Female & Male & $-23,18$ & 3113 & $-0,01$ & 0,99 \\
\hline & Farmers & $\begin{array}{l}\text { Hydroelectric } \\
\text { company }\end{array}$ & 2,43 & 1,75 & 1,39 & 0,16 \\
\hline & & Truism y services & $-0,16$ & 1,91 & $-0,08$ & 0,93 \\
\hline & & Housewife & 24 & 3113 & 0,01 & 0,99 \\
\hline \multirow[t]{3}{*}{ Education } & No formal & Primary education & 1,33 & 1,48 & 0,90 & 0,37 \\
\hline & education & $\begin{array}{l}\text { Secondary } \\
\text { education }\end{array}$ & 5,23 & 2,65 & 1,98 & $0,05^{*}$ \\
\hline & & High education & 26,33 & 3113 & 0,01 & 0,99 \\
\hline \multicolumn{2}{|l|}{ Age } & & 0,10 & 0,05 & 2,07 & $0,04^{*}$ \\
\hline \multirow[t]{3}{*}{ Location } & Batiruana & Escaba de Abajo & $-0,52$ & 1,70 & $-0,30$ & 0,76 \\
\hline & & Escaba de Arriba & 1,48 & 2,22 & 0,67 & 0,50 \\
\hline & & Villa de Escaba & $-2,52$ & 2,23 & $-1,13$ & 0,26 \\
\hline \multicolumn{3}{|c|}{ Degree of knowledge } & $-0,02$ & 0,03 & $-0,54$ & 0,59 \\
\hline \multirow{2}{*}{$\begin{array}{l}\text { Degree of } \\
\text { contact }\end{array}$} & Low & Moderate & $-18,01$ & 10750 & 0,00 & 1,00 \\
\hline & & Direct & $-18,34$ & 10750 & 0,00 & 1,00 \\
\hline
\end{tabular}

${ }^{*} \mathrm{P}<0.05$. AIC model: $62,547$.

Table 2. Results of the GLM for the response variable "moralistic evaluation of the bats by the people".

\begin{tabular}{|c|c|c|c|c|c|c|}
\hline \multicolumn{3}{|l|}{$\begin{array}{l}\text { Coefficient } \\
\text { Intercept }\end{array}$} & $\begin{array}{l}\text { Estimate } \\
-53,5313\end{array}$ & $\begin{array}{l}\text { Stand error } \\
18332,9427\end{array}$ & $\begin{array}{l}Z \text { value } \\
-0,003\end{array}$ & $\begin{array}{l}\operatorname{Pr}(>|z|) \\
0,9977\end{array}$ \\
\hline \multirow{4}{*}{$\begin{array}{l}\text { Gender } \\
\text { Occupation }\end{array}$} & Female & Male & 2,9357 & 3,6648 & 0,801 & 0,4231 \\
\hline & Farmers & $\begin{array}{l}\text { Hydroelectric } \\
\text { company }\end{array}$ & 12,7325 & 6,2925 & 2,023 & 0,0430 * \\
\hline & & Tourism and services & 8,5949 & 6,4616 & 1,330 & 0,1835 \\
\hline & & Housewife & 12,5637 & 23,8786 & 0,526 & 0,5988 \\
\hline \multirow[t]{3}{*}{ Education } & formal & Primary education & 10,6387 & 23,6008 & 0,451 & 0,6521 \\
\hline & education & Secondary education & 0,2390 & 23,6977 & 0,010 & 0,9920 \\
\hline & & High education & $-8,6294$ & 7643,3486 & $-0,001$ & 0,9991 \\
\hline Age & & & 0,0882 & 0,1565 & 0,564 & 0,5730 \\
\hline \multirow[t]{3}{*}{ Location } & Batiruana & Escaba de Abajo & 22,2492 & 4661,3912 & 0,005 & 0,9962 \\
\hline & & Escaba de Arriba & 23,5665 & 4661,3914 & 0,005 & 0,9960 \\
\hline & & Villa de Escaba & 27,9566 & 4661,3937 & 0,006 & 0,9952 \\
\hline \multicolumn{2}{|c|}{ Degree of knowledge } & & $-0,2706$ & 0,1442 & $-1,876$ & 0,0607 \\
\hline \multirow{2}{*}{\multicolumn{2}{|c|}{ Degree of Low }} & Moderate & 15,2810 & 17730,3858 & 0,001 & 0,9993 \\
\hline & & Direct & 20,2845 & 17730,3851 & 0,001 & 0,9991 \\
\hline
\end{tabular}




\section{DISCUSSION}

\section{Local knowledge about bats}

The people of the area of Escaba use the type of feeding of the bats as a general classification criterion, mentioning mainly the hematophagous and insectivorous, recognizing in this way a diversity of bat species much lower than the one actually registered in the area, according to Costa Rego and colleagues (2015). At the taxonomic group level, people assume that bats are rodents because of their morphological similarity and do not always identify that both groups are mammals. People identify, almost exclusively, that bats live in human constructions and reflect a great knowledge regarding the management ways to avoid or make exclusions.

Because most of the species occurring in the study area are insectivorous, it is likely that local knowledge reflects greater familiarity with these species, while the existence of other groups (carnivorous, hematophagous, nectivorous and frugivorous bats) is neglected. In this way, the contribution of nature related to the consumption of insects that can be annoying for people, is highlighted for local knowledge. Added to this, besides the knowledge about the existence of the vampire and the damage it can cause, especially to livestock, the ecological value attributed to insectivorous bats living in the dam was high. The high diversity of bats in other latitudes allows people a direct contact with species that feed on other resources such as fruits and nectar (Galarza and Aguirre, 2007; López del Toro et al., 2009).

With respect to the transmission of diseases by bats, more than half of the interviewees said that they do not transmit any. Although a deeper analysis is necessary, this result does not agree with other studies (Cousins and Compton, 2005; Castilla and Viñas, 2012; Barnes, 2013), where bats are clearly identified with the transmission of rabies. Although Prokop and colleagues (2009) relate the aversion by spiders, snakes and bats to the theory of the avoidance of the disease, this seems not to happen with the local people in Escaba. The dissemination of information about the transmission of diseases is probably necessary; especially the rabies, by wild and domestic animals, because people declared not having precautions when they come in contact with the bats and even many of them do not provide vaccines to their pets.

The present use of guano as a fertilizer was mentioned many times in the area of Escaba, whereas in urban areas of Argentina it is rarely mentioned (Castilla and Viñas, 2012). The large accumulation of feces produced by the colony is seen as an opportunity of use: commercialization or distribution at the local level. But, at the same time, the local people mention that the company does not agree with them using that resource.

The legend or myth that old rodents become bats is widespread throughout Latin America (Pérez et al. 2003; Retana Guiascón 2012), even in the Escaba zone, stimulated by the morphological similarities. Some conceptions that consider that all bats suck blood or are blind are usually taken by bat conservation programs as myths and misconceptions, whereas that various authors refer to them as alternative conceptions (Prokop and Tunnicliffe, 2008; Prokop et al., 2009; Navarro Noriega, 2015). These conceptions aim to make the world more predictable and controllable (Chi, 1992. Prokop et al., 2009), they have a sensory, cultural and school origin and are 
transmitted from generation to generation (Lahitte et al., 1989). For example, referring to the fact that bats are blind can suggest the knowledge that vision is not their main form of orientation since they are nocturnal; assume that all bats are hematophagous and therefore dangerous gives a signal of attention and valuable alarm to avoid taking risks in case of an encounter or for the management of livestock.

\section{Perceptions, attitudes and actions towards bats.}

Previous studies have found that, in general, the perception of people about bats is negative and it is related the appearance of these animals and the damage they can cause if they feed livestock blood or take refuge in a human building structure (Sheeline, 1991; Prokop et al., 2009; Castilla and Viñas, 2012). However, in the present study, $44 \%$ of the people had positive perceptions of bats, the highest percentage compared to previous researches. This positive perception increases with the age of the people and is higher in people who have completed secondary education. In a study conducted by Barnes (2013) high school students had more knowledge about bats than elementary students; and this higher level of information could help improve the perception of bats (López del Toro et al., 2009; Navarro Noriega, 2015). When visiting the secondary school in the area, it was noticed that the colony is a topic addressed daily in class and in science presentations, so it was expected that those who attended the secondary school have more information about bats in general and related with the colony.

The relation of local people with bats surpasses a type of "symbolic" value according to Kellert (1997), certainly influenced by the presence of the colony. Perhaps it would be necessary to add an "identity" value (Lameda Camacaro, 2011) considering that the sense of belonging of a resident pass through an element of nature. While some studies found differences in the moralistic assessment between men and women (Kellert and Berry, 1987; Eagles and Demare, 1999), these results show that workers of the hydroelectric company were who expressed a "moralistic" value. It could be a result of a company policy probably encouraged from governmental and scientific sectors.

In conservation sites of large bat colonies such as caves or bridges, where studies on social perspectives have been carried out (Pennisi et al., 2004; Taylor, 2007; Gómez Ruiz et al., 2015, Navarro Noriega, 2015), the utilitarian sense of bats reflected in the valuation of ecosystem services and ecotourism had been pointed out. But until now this affective bond has not been registered, which coexists with the utilitarian sense.

Inquiring about the traditional knowledge (practices) used to resolve conflicts, specifically the exclusions, was appropriate to evaluate the tendency to a positive or negative attitude. It is surprising the acceptance of bat presence inside people homes and, in addition, the preference for non-lethal ways to exclude bats or even live with them. We found that this positive attitude could be related to the age of the inhabitant, in accordance with what has been found by other authors (Kellert and Berry, 1987). The tendency of women not to use forms of lethal exclusion with bats can be explained by the fact that women have a more affective relationship with the fauna than men (Serpell, 2004), but these results should be expanded.

Achieving a change in attitudes and 
actions on biodiversity and to conserve an ecosystem resource or service, requires that this educational strategy have simple and clear messages and activities that are maintained over time and involve direct contact with nature (Campos et al., 2013). Understand that the actors involved in the conservation of biodiversity (politicians, administrators, researchers, etc.) have scales of values, construction systems, knowledge and different interests, it is vital to achieve environmental sustainability (Altieri and Toledo, 2011); and the necessary knowledge must be co-constructed among all these local actors, since they are part of the same system (Lahitte and Bacigalupe, 2007). The perception and attitude reflect the traditional uses, the forms of conflict management and the conservation strategies that people practice intuitively in their communities and this must be the basis of the environmental education strategy that collaborates with the action plan. the conservation of the enormous colony of the dike and of the rest of the species of bats of the place.

\section{ACKNOWLEDGEMENTS}

We are thankful the residents of Escaba who welcomed us and offered their knowledge. To those who participated in the field work. To CONICET for the scholarship awarded to finish the doctorate that gave birth to this work. We especially appreciate the anonymous reviewer for his valuable contributions. Cecilia Castilla wants to thank her family for accompanying this training journey.

\section{REFERENCES}

Aguirre LF, Nassar JM, Barquez RM, Medellín RA, Navarro Noriega L, Rodríguez Durán A and Rodríguez Herrera B (2014). De esfuerzos locales a una iniciativa regional: La Red Latinoamericana y del Caribe para la Conservación de los Murciélagos (RELCOM). Ecología en Bolivia 49(2):45-50.

Aguirre LF, Medellín RA y Rodríguez Herrera B (2016). From threat to opportunity strategies for bat conservation in the Neotropics. In: Aguirre AA y Sukumar R (eds.). Tropical Conservation: Perspectives on Local and Global Priorities. Oxford University Press, pp.140-153.

Albuquerque UP, Lucena RF, Cunha LV and Alves RRN (2016). Methods and techniques in ethnobiology and ethnoecology. Humana Press.

Altieri M and Toledo VM (2011). The agroecological revolution of Latin America: rescuing nature, securing food sovereignty and empowering peasants. The Journal of Peasant Studies 38(3): 587-612.

Alves RRN and Albuquerque UP (2017). Ethnozoology: Animals in Our Lives. Academic Press.

Bagstad KJ and Wiederholt R (2013). Tourism values for Mexican free-tailed bat viewing. Human Dimensions of Wildlife 18(4):307-311.

Barnes P (2013). Battitude: An assessment of human attitude and behaviour towards the critically endangered Pteropus rodricensis. Doctoral Thesis. Imperial Collage London.

Bernard $R$ (1995). Search methods in Anthropology (2nd. ed.). Altamira Press, USA.

Burkart R, Bárbaro N, Sánchez RO and Gómez DA (1999) Eco-regiones de la Argentina. Administración de Parques Nacionales. Buenos Aires. Argentina.

Cacioppo JT, Petty RE and Geen TR (1989). From the tripartite to the homeostasis model of attitudes. Pp. 275-305, en: Pratkanis AR (ed). Attitude structure and function. Psychology Press.

Campos CM, Nates $\mathrm{J}$ and Lindemann Matthies $\mathrm{P}$ (2013). Percepción y conocimiento de la biodiversidad por estudiantes urbanos $y$ 
rurales de las tierras áridas del centro-oeste de Argentina. Ecología Austral 23:174-183.

Castilla MC y Viñas M (2012). Percepción sobre murciélagos urbanos y su manejo en San Fernando del Valle de Catamarca, Argentina. In Comunidad de Manejo de Fauna Silvestre (COMFAUNA). Memorias del $X$ Congreso Internacional de Fauna Silvestre de América Latina, Salta, Argentina, pp. 1-5.

Chi MTH (1992). Conceptual change within and across ontological categories: examples from learning and discovery in science. In Giere R (ed.). Cognitive models of science: Minnesota studies in the philosophy of science. University of Minnesota Press, pp. 129-186.

Clucas B, McHugh K and Caro T (2008). Flagship species on covers of US conservation and nature magazines. Biodiversity and Conservation 17:1517-1528.

Costa Neto EM, Fita DS and Clavijo Vargas M (2009). Manual de Etnozoología: Una guía teórico-práctica para investigar la interconexión del ser humano con los animales. Tundra, España.

Costa Rego KM, Zeppelini CG, Serramo Lopez LC, Alves RRN (2015). Assessing human-bat interactions around a protected area in northeastern Brazil. Journal of Ethnobiology and Ethnomedicine 11:80.

Cousins JA and Compton SG (2005). The Tongan flying fox Pteropus tonganus: status, public attitudes and conservation in the Cook Islands. Oryx 39(2):196-203.

Czech, B and Krausman, PR (2001) The endangered species act: history, conservation biology, and public policy. JHU Press, EEUU.

De Prada SS and Barragán-Tabares LM (2018). Relatos y percepciones sobre murciélagos por parte de la comunidad Tocagón en Otavalo Ecuador. Ethnoscientia 3:1-5.

Díaz MM, Carbajal MN, Lipps E, Lutz MA, Rosenfeld S and Barquez RM (2013). El estado de conservación de los murciélagos de Argentina. In: Porini G y Ramadori D. Manejo de fauna silvestre en la Argentina. Programas de conservación de especies amenazadas. Dirección de Fauna Silvestre de la Secretaría de Ambiente y Desarrollo Sustentable de Nación, Argentina, pp. 273-281.

Eagly $\mathrm{AH}$ and Chaiken S (1993). The
Psychology of Attitudes. 1st ed., Cengage Learning.

Eagles PFJ and Demare R (1999). Factors influencing children's environmental attitudes. The Journal of Environmental Education 30(4):33-37.

Frank EF (1998). History of the guano mining industry, Isla de Mona, Puerto Rico. Journal of Cave and Karst Studies 60(2):121-125.

Galarza MI and Aguirre LF (2007). Conservación de los Murciélagos de Bolivia. En: Aguirre LF (ed.). Historia Natural, Distribución y conservación de los Murciélagos de Bolivia. Centro de ecología y difusión Simón I. Patiño. Santa Cruz, Bolivia pp. 89-136.

Gamboa Alurralde S, Barquez RM y Díaz MM (2017). New records of bats (Mammalia: Chiroptera) for a southern locality of the Argentine Yungas. Check List 13(3):1-8.

Gamboa Alurralde S, Sánchez RT, Barquez RM and Díaz MM (2016). New records of bats (Chiroptera, Mammalia) from Argentina. Check List 12(2):1-11.

Gamboa Alurralde S, Díaz MM, Gaudioso PJ, Krapovickas L, López Berrizbeitia MF, Pérez MJ and Sánchez RT (2014). La colonia de murciélagos más grande de Sudamérica: situación actual. Informe final becas $\mathrm{BCl}$ RELCOM 2013-2014. Programa de Conservación de los Murciélagos de Argentina.

Gómez Ruiz EP, Jimenez C, Flores Maldonado JJ, Lacher TE and Packard JM (2015). Conservación de murciélagos nectarívoros (Phyllostomidae: Glossophagini) en riesgo en Coahuila y Nuevo León. Therya 6(1):89-102.

Gunnthorsdottir A (2001). Physical attractiveness of an animal species as a decision factor for its preservation. Anthrozoös 14,204-215.

Heywood, VH (1995). Global biodiversity assessment. United Nations Environment Program. Cambridge University Press, Cambridge, UK.

International Society of Ethnobiology (2006). International Society of Ethnobiology Code of Ethics (with 2008 additions). http:// ethnobiology.net/code-of-ethics/. Accessed 13 February 2019

Isma'll A (2015). Survey of bat roosts in some primary and secondary schools and the attitudes of students towards bats in Zaria, 
Nigeria. Master thesis. Master's in educational biology, Ahmadu Bello University, Zaria Nigeria.

Kellert SR (1997). The value of life: Biological diversity and human society. Island Press.

Kellert SR and Berry JK (1987). Attitudes, knowledge, and behaviors toward wildlife as affected by gender. Wildlife Society Bulletin 15(3):363-371.

Kingston T (2016). Cute, Creepy, or Crispy. How values, attitudes, and norms shape human behavior toward bats. In: Voig CC y Kingston $\mathrm{T}$ (eds.). Bats in the Anthropocene: Conservation of Bats in a Changing World. Springer International Publishing, pp. 571-595.

Knight AJ (2008). "Bats, snakes and spiders, Oh my!" How aesthetic and negativistic attitudes, and other concepts predict support for species protection. Journal of Environmental Psychology 28(1):94-103.

Kühn F and Rohemeder G (1943). Estudio Fisiogeográfico de las Sierras de Tucumán. Monografía 3. Universidad Nacional de Tucumán, Argentina.

Kunz TH (1984). Halloween Treat: Bat Facts and Folklore. American Biology Teacher 46(7): 394-99.

Kunz TH, Braun de Torrez E, Bauer D, Lobova T and Fleming TH (2011). Ecosystem service provided by bats. Annals of the New York Academy of Sciences 1223:1-38.

Lahitte HB and Bacigalupe AM (2007). Observación y conocimiento: Relevancia del investigador en la construcción de la Antropología como ciencia cognitiva. Fermentum. Revista Venezolana de Sociología y Antropología 17(49):407-418.

Lahitte HB, Hurrell J and Malpartida A (1989). Relaciones 2: Crítica y expansión de la ecología de las ideas. Ediciones Nuevo Siglo, La Plata.

Lameda Camacaro FI (2011). Etnozoología del oso andino (Tremarctos ornatus) en el Noroeste de Argentina y la Cordillera Andina de Venezuela. MSc. Disertación, Universidad Nacional de Salta, Salta, Argentina.

Leader Williams $\mathrm{N}$ and Dublin HT (2000). Charismatic megafauna as flagship species. In: Entwistle, A. y N. Dunstone. Priorities for the conservation of mammalian diversity: has the panda had its day?. Cambridge University Press, pp. 53-81.

Lizarro D, Galarza MI and Aguirre LF (2010). Tráfico y comercio de murciélagos en Bolivia. Revista Boliviana de Ecología y Conservación Ambiental, 27:63-75.

López del Toro P, Andresen E, Barraza L and Estrada A (2009). Attitudes and knowledge of shade-coffee farmers towards vertebrates and their ecological functions. Tropical Conservation Science 2(3):299-318.

Madeiros MFT, Alves ÂGC, Costa Neto EM, Neto EMFL, Dal Sogli FK and Souto FJB. (2016). Dictionary of Ethnobiology and Related Areas. In: Albuquerque $U$ and Nóbrega Alves $R$ (eds). Introduction to Ethnobiology. Springer, Cham, pp. 274-303.

Martín-López B, Gómez Baggethun E, García Llorente M y Montes C (2014). Trade-offs across value-domains in ecosystem services assessment. Ecological Indicators 37:220-228.

MEA (2005). Ecosystems and human wellbeing. Millennium Ecosystem Assessment. Island Press, Washington, D.C., USA.

Miller JR and Hobbs RJ (2002). Conservation where people live and work. Conservation Biology 16(2):330-337.

Miotti, MD. (2014). SICOM Dique Escaba. Red Latinoamericana para la Conservación de los Murciélagos. Programa de Conservación de Murciélagos de Argentina. 11p.

Mon, R and Urdaneta A (1972). Introducción a la geología de Tucumán, República Argentina. Revista de la Asociación Geológica Argentina 27(3):309-329.

Mosa SG (2014). Riesgos potenciales y reales del confinamiento de murciélagos en un embalse: caso del dique Escaba, Argentina. Memorias del $X$ Congreso Internacional de Fauna Silvestre de América Latina, Salta, Argentina, 1-12 pp.

Musila S, Prokop P and Gichuki N (2018). Knowledge and perceptions of, and attitudes to, bats by people living around Arabuko Sokoke Forest, Malindi Kenya. Anthrozoös 31(2):247-262.

Navarro Noriega L (2015). Las 
murciélagos en México. Doctoral Thesis. Doctorado Interuniversitario de Educación Ambiental. Universidad Autónoma de Madrid.

Pennisi LA, Holland SM and Stein TV (2004). Achieving bat conservation through tourism. Journal of Ecotourism 3(3):195-207.

Pérez JL, Gómez AG and Gómez SRR (2003). Clasificación tradicional de los vertebrados terrestres en dos comunidades nahuas de Tlaxcala, México. Etnobiología 3(1):1-19.

Prokop P and Tunnicliffe SD (2008). Disgusting animals: Primary school children's attitudes and myths of bats and spiders. Eurasia Journal of Mathematics, Science and Technology Education 4(2):87-97.

Prokop P, Fančovičová J and Kubiatko M (2009). Vampires are still alive: Slovakian students' attitudes toward bats. Anthrozoös 22(1):19-30.

Prokop P and Fančovičová J. (2013). Does colour matter? The influence of animal warning colouration in human emotions and willingness to protect them. Animal Conservation 16, 458-466.

Prokop P, Medina-Jerez W, Coleman J, Fančovičová J, Özel M, Fedor P. (2016). Tolerance of frogs among high school students: Influences of disgust and culture. Eurasia Journal of Mathematics, Science and Technology Education 12(6):1499-1505.

Purdy, KG and Decker DJ (1989). Applying wildlife values information in management: the wildlife attitudes and values scale. Wildlife Society Bulletin, 17:494-500.

Regidor H, Mosa S and Núñez A (2003). Confinamiento de una colonia de Tadarida brasiliensis, una alternativa de manejo compatible con la conservación. Chiroptera Neotropical 9(1-2):157-162.

Retana Guiascón, OG and Navarijo Ornelas ML (2012). Los valores culturales de los murciélagos. Revista Mexicana de Mastozoología 2:21-28.

Reyers B, Biggs R, Cumming GS, Elmqvist T,
Hejnowicz AP y Polasky S (2013). Getting the measure of ecosystem services: a socialecological approach. Frontiers in Ecology and Environment 11(5):268-273.

RStudio Team (2015). RStudio: Integrated Development for R. RStudio, Inc., Boston, MA URL http://www.rstudio.com/.

Santillán de Andres SE and Ricci T (1980). Geografía de Tucumán. Facultad de Filosofía y Letras. Universidad Nacional de Tucumán.

Serpell J (2004). Factors influencing human attitudes to animals and their welfare. Jourmal of Animal Welfare 13:145-151.

Shafie NJ, Sah SAM, Mutalib AHA and Fadzly N (2017). General perceptions and awareness level among local residents in Penang Island toward bats conservation efforts. Tropical Life Sciences Research 28(2):31-44.

Sheeline L (1991). Cultural significance of Pacific Fruit Bats (Pteropus) to the Chamorro people of Guam. Report to World Wildlife Fund. TRAFFIC USA. Washington, DC.

Simberloff $D$ (1998). Flagships, umbrellas, and keystones: is single-species management passé in the landscape era?. Biological conservation 83(3):247-257.

Sitas N, Baillie JEM. and Isaac NJB (2009). What are we saving? Developing a standardized approach for conservation action. Animal Conservation 12(3):231-237.

Tapper R (2006). Wildlife watching and tourism: a study on the benefits and risks of a fast-growing tourism activity and its impacts on species. World Wildlife Fund.

Taylor ES and Butler DR (2007). Geography student knowledge of bats and Austin Bat Colonies. Southwestern Geographer 11:231243.

Vargas Melgarejo L (1994). Sobre el concepto de percepción. Alteridades 4(8):47-53.
Received: 29 October 2018

Accepted: 10 March 2019

Published: 26 July 2019 